\title{
KARAKTERISTIK DAN TINGKAT KONSUMSI VITAMIN B6, B12, DAN ASAM FOLAT PADA PASIEN STROKE RAWAT INAP
}

\author{
Novita Rahayu Lestari ${ }^{{ }^{*}}$, Suhaema ${ }^{1}$, Ni Ketut Sri Sulendri ${ }^{1}$ dan Fifi Luthfiyah ${ }^{1}$ \\ ${ }^{1}$ Jurusan Gizi, Poltekkes Kemenkes Mataram, Indonesia \\ Jalan Praburangkasari Dasan Cermen, Sandubaya Kota Mataram \\ Telp./Fax. (0370) 633837, \\ Email : novitarahayu808@gmail.com
}

\begin{tabular}{l} 
Article Info \\
\hline Article history: \\
Received July $16^{\text {th }}, 2019$ \\
Revised August $25^{\text {th }}, 2019$ \\
Accepted September $27^{\text {th }}, 2019$
\end{tabular}

Keyword:

Level of consumption of vitamins B6, B12, and folic acid; Stroke

\begin{abstract}
Background. Stroke is a cerebrovascular disease (cerebral blood vessel) that is characterized by impaired brain function due to damage or death of brain tissue due to reduced or blocked blood flow and oxygen to the brain. Stroke is influenced by several factors, namely risk factors that cannot be controlled, and risk factors that can be controlled. Risk factors that cannot be controlled include age, gender, smoking habits, and risk factors that can be controlled consisting of a history of hypertension, a history of diabetes mellitus, and hypercholesterolemia. Todetermine the description of the level of consumption of vitamins B6, B12, and folic acid in Stroke Patients Hospitalized in the BRSUD of Tabanan Regency.
\end{abstract}

Research Methods. The type of research conducted is Descriptive Observational.

Research Result. Based on age, as many as 5 people (71\%). $\geq 55$ years old. The sex of the most subjects having strokes was women with 4 people (57\%). Distribution of the type of work of the subject is entrepreneur as many as 4 people (57\%), civil servants 1 person (14\%) and not working as many as 2 people (29\%). Nutritional status of 1 person (14\%) malnutrition, 1 person (14\%) overweight, and 5 people $(72 \%)$ good nutrition. Subjects with a history of hypertension were 6 people (86\%), and those with a history of hypercholesterolemia as many as 2 people (29\%). Subjects who had smoking habits were 1 person (14\%). The level of consumption of Vitamin B6, B12, and folic acid in stroke patients, it is known that all subjects have a low consumption level $(<80 \%)$ with details of vitamin B6 (4.50\%), B12 (0.29\%), Folic Acid (20,0\%).

Conclusion. From this study all patients who suffered strokes consumed less vitamin B6, B12, and folic acid.

Copyright $\odot$ Jurnal Gizi Prima All rights reserved.

\section{PENDAHULUAN}

Stroke merupakan salah satu penyakit kronis yang dapat menyebabkan tidak seimbangnya fungsi tubuh bagi seseorang yang mengalaminya. Hal tersebut tentu saja akan menghambat produktifitas. Stroke dapat menyebabkan kematian dan menempati urutan ketiga di Indonesia setelah penyakit kanker dan jantung (Susilawati dan Nurhayati, 2018).

Berdasarkan data World Health Organization (WHO) sebanyak 17.5 juta kematian disebabkan oleh penyakit kardiovaskuler, dengan jumlah estimasi sebanyak 7.4 juta kematian disebabkan oleh penyakit jantung dan 6.7 juta kematian disebabkan oleh penyakit stroke (WHO, 2014). 
Berdasarkan data Word Stroke Organization tahun 2017 mengungkapkan bahwa jumlah kasus stroke di seluruh dunia sebesar 17 juta jiwa dengan 6,5 juta jiwa kematian akibat stroke. Dan data yang dikeluarkan oleh American Heart Association [AHA] 2017 melaporkan bahwa 1 dari 6 orang di dunia akan mengalami stroke, setiap 2 detik seseorang di dunia akan mengalami stroke dan $80 \%$ stroke ulangan akibat sumbatan dapat dicegah.

Di Indonesia menurut data Riset Kesehatan Dasar (Riskesdas) tahun 2013 terjadi peningkatan prevalensi stroke tahun 2007 yaitu dari 8,3\% menjadi 12,1\%. Sejalan dengan pernyataan tersebut di provinsi Bali prevalensi terjadinya stroke tahun 2007 mengalami peningkatan yaitu dari $6,8 \%$ menjadi 8,9\% pada tahun 2013.

Penyebab stroke adalah pecahnya pembuluh darah di otak atau terjadinya thrombosis dan emboli. Gumpalan darah akan masuk kealiran darah sebagai akibat dari penyakit lain atau karena adanya bagian otak yang cedera dan menyumbat arteri otak, akibatnya fungsi otak berhenti dan menjadi penurunan fungsi otak (Pajri dan Dewi, 2018). Terdapat dua tipe utama dari stroke yaitu stroke iskemik akibat berkurangnya aliran darah sehubungan dengan penyumbatan (thrombosis, emboli), dan hemoragik akibat pendarahan. (WHO, 2014).

Beberapa faktor risiko stroke yaitu faktor risiko yang tidak dapat dikontrol, dan faktor risiko yang dapat dikontrol. Faktor risiko yang tidak dapat dikontrol diantaranya usia, ras, jenis kelamin, kebiasaan merokok, dan faktor risiko yang dapat dikontrol terdiri atas riwayat hipertensi, riwayat diabetes mellitus, dan hiperkolestrolemia (Pajri dan Dewi, 2018). Seseorang dengan diabetes mellitus rentan untuk menjadi aterosklerosis, hipertensi, obesitas, dan gangguan lemak darah. Seseorang yang mengidap diabetes mempunyai risiko serangan stroke iskemik 2 kali lipat dibandingkan mereka yang tidak diabetes, sedangkan seseorang yang mengidap hipertensi mempunyai risiko serangan stroke iskemik sebanyak enam kali (Indrawati, 2016).

Menurut Patricia (2015) hipertensi memegang peranan penting pada patogenesis aterosklerosis pembuluh darah besar yang selanjutnya akan menyebabkan stroke iskemik oleh karena oklusi trombotik arteri, emboli arteri ke arteri atau kombinasi keduanya. Diabetes mellitus mampu menebalkan dinding pembuluh darah otak yang berukuran besar. Menebalnya dinding pembuluh darah otak akan menyempitkan diameter pembuluh darah dan penyempitan tersebut kemudian akan mengganggu kelancaran aliran darah ke otak, yang pada akhirnya akan menyebabkan infark sel-sel otak. Demikian juga dengan kadar kolesterol yang tinggi mendistribusikan pembentukan plak di arteri yang memasok oksigen ke jantung dan otak.

Berdasarkan penjelasan hasil penelitian di atas menurut Mardiana, (2017) hal tersebut merupakan akibat dari defisiensi vitamin B6, B12, dan asam folat. Vitamin B6, B12, dan asam folat merupakan zat gizi yang mempunyai peran penting dalam menjaga kesehatan saraf. Vitamin B12 dan asam folat melindungi pembuluh darah arteri dari kerusakan akibat pengaruh homosistein.

Salah satu upaya pencegahan yang dapat dilakukan untuk menanggulangi terjadinya serangan berulang atau kekambuhan pada penderita Stroke adalah dengan menjalankan perilaku hidup sehat. Pengendalian faktor risiko secara optimal, melakukan kontrol secara rutin, mengkonsumsi makanan yang sehat dan tidak merokok. Serta harus mengenali tanda-tanda dini kejadian Stroke (Nurdiani, dkk. 2018).

Berdasarkan uraian di atas peneliti tertarik untuk melakukan penelitian mengenai gambaran konsumsi vitamin B6, B12, dan asam folat pada pasien stroke rawat inap di Rumah Sakit Tabanan?

\section{METODE PENELITIAN}

Jenis penelitian yang dilakukan adalah Observasional Deskriptif dengan menggunakan pendekatan Cross sectional. Dalam hal ini rancangan penelitian tersebut bertujuan untuk mengetahui gambaran tingkat konsumsi vitamin B6, B12 dan asam folat pada pasien stroke rawat inap di BRSUD Tabanan.

Data yang dikumpulkan yaitu: Data primer karakteristik subjek berdasarkan usia, jenis kelamin, pekerjaan, riwayat penyakit, dan kebiasaan merokokdikumpulkan dengan cara wawancara secara langsung dengan media kuesionerserta alat bantu form identitas, status gizi dihitung menggunakan persentil LILA, tingkat konsumsi vitamin B6, B12 dan asam folatdikumpulkan dengan metode food weighing yaitu dengan cara 
menimbang sisa makan pasien selama menjalani perawatan di rumah sakit. Data sekunder karakteristik pasien terdiagnosa mengalami strokedilihat pada buku rekam medis pasien.

\section{HASIL PENELITIAN}

\section{Karakteristik Subjek Peneliti}

Penelitian ini telah dilakukan pada subjek yang terdaftar pada bulan Mei 2019 sebagai pasien stroke rawat inap di ruang High Care Unit (HCU)BRSUD Tabanan Bali, yang bersedia berpartisipasi dalam penelitian dinyatakan secara tertulis dengan form informed consen.Subjek penelitian berjumlah 7 orang. Karakteristik subjek berdasarkan usia, jenis kelamin, pekerjaan dan status gizi disajikan pada tabel 1 .

Tabel 1. Karakteristik Subjek Penelitian

\begin{tabular}{|c|c|c|}
\hline Karakteristik & $\mathbf{n}$ & $(\%)$ \\
\hline \multicolumn{3}{|l|}{ Usia } \\
\hline$<55$ tahun & 2 & 29 \\
\hline$\geq 55$ tahun & 5 & 71 \\
\hline Total & 7 & 100 \\
\hline \multicolumn{3}{|l|}{ Jenis kelamin } \\
\hline Laki-laki & 3 & 43 \\
\hline Perempuan & 4 & 57 \\
\hline Total & 7 & 100 \\
\hline \multicolumn{3}{|l|}{ Pekerjaan } \\
\hline PNS & 1 & 14 \\
\hline Wiraswasta & 4 & 57 \\
\hline Tidak Bekerja & 2 & 29 \\
\hline Total & 7 & 100 \\
\hline \multicolumn{3}{|l|}{ Status Gizi } \\
\hline Overweight & 1 & 14 \\
\hline Gizi baik & 5 & 72 \\
\hline Gizi buruk & 1 & 14 \\
\hline Total & 7 & 100 \\
\hline
\end{tabular}

55 tahun yaitu sebanyak 5 orang $(71 \%)$, jenis kelamin terbanyak menderita stroke yaitu perempuan sebanyak 4 orang $(57 \%)$. Karakteristik subjek menurut pekerjaan yaitu subjek dengan jenis pekerjaan wiraswasta sebanyak 4 orang (57\%). Sedangkan untuk karakteristik status gizi subjek yang diperoleh berdasarkan persentil LILA menunjukkan bahwa sebanyak 1 orang (14\%) overweight, gizi baik 5 orang (72\%), dan gizi buruk 1 orang (14\%). Dengan demikian dapat disimpulkan pada penelitian ini dominan subjek memiliki status gizi baik. Pengukuran yang dilakukan dengan menggunakan LILA dikarenakan pasien tidak dapat berdiri.

Tabel 2. Karakteristik Subjek Berdasarkan Riwayat Penyakit

\begin{tabular}{|c|c|c|}
\hline Karakteristik & n & $(\%)$ \\
\hline \multicolumn{3}{|l|}{ Hipertensi } \\
\hline Ya & 6 & 86 \\
\hline Tidak & 1 & 14 \\
\hline Total & 7 & 100 \\
\hline \multicolumn{3}{|l|}{ Hiperkolestrolemia } \\
\hline Ya & 2 & 29 \\
\hline Tidak & 5 & 71 \\
\hline Total & 7 & 100 \\
\hline \multicolumn{3}{|l|}{ Jantung Koroner } \\
\hline Ya & 3 & 43 \\
\hline Tidak & 4 & 57 \\
\hline Total & 7 & 100 \\
\hline
\end{tabular}


Berdasarkan tabel karakteristik subjek berdasarkan riwayat penyakit sebanyak 6 orang (86\%) memiliki riwayat penyakit hipertensi, sebanyak 2 orang (29\%) memiliki riwayat penyakit hiperkolestrolemia. Dan sebanyak 3 orang (43\%) memiliki riwayat penyakit jantung.

Tabel 3. Karakteristik Subjek Berdasarkan Kebiasaan Merokok

\begin{tabular}{lcc}
\hline \multicolumn{1}{c}{ Karakteristik } & n & $(\boldsymbol{\%})$ \\
\hline Kebiasaan merokok & & \\
Kadang-kadang & 1 & 14 \\
Tidak pernah & 6 & 86 \\
Total & 7 & 100 \\
\hline
\end{tabular}

Berdasarkan hasil penelitian diketahui bahwa 1 orang (14\%) memiliki kebiasaan merokok dengan frekuensi merokok maksimal 6 kali dalam seminggu dan dalam satu hari dapat menghabiskan 2 batang rokok. Subjek berhenti merokok setelah MRS dan terdiagnosa memiliki penyakit stroke.

Tingkat Konsumsi Vitamin B6, B12 dan Asam Folat

Asupan zat gizi pada penelitian ini didapatkan dengan metode food weighing yaitu menimbang sisa makan subjek selama menjalani perawatan di rumah sakit. Asupan zat gizi dapat dilihat pada tabel 4.

Tabel 4. Tingkat Konsumsi Vitamin B6, Asam Folat, Vitamin B12

\begin{tabular}{|c|c|c|c|c|c|c|c|c|c|}
\hline \multirow[b]{2}{*}{ Subjek } & \multicolumn{3}{|c|}{ Asupan } & \multicolumn{3}{|c|}{ Kebutuhan } & \multicolumn{3}{|c|}{$\%$ tingkat konsumsi } \\
\hline & $\begin{array}{c}\text { Vitamin } \\
\text { B6 } \\
(\mathrm{mg})\end{array}$ & $\begin{array}{c}\begin{array}{c}\text { Asam } \\
\text { folat }\end{array} \\
\text { (mcg) }\end{array}$ & $\begin{array}{l}\text { Vitami } \\
\text { n B12 } \\
\text { (mcg) }\end{array}$ & $\begin{array}{c}\text { Vitami } \\
\text { n B6 } \\
\text { (mg) }\end{array}$ & $\begin{array}{c}\begin{array}{c}\text { Asam } \\
\text { folat }\end{array} \\
\text { (mcg) }\end{array}$ & $\begin{array}{l}\text { Vitami } \\
\text { n B12 } \\
\text { (mcg) }\end{array}$ & $\begin{array}{c}\text { Vitami } \\
\text { n B6 } \\
(\mathrm{mg})\end{array}$ & $\begin{array}{c}\begin{array}{c}\text { Asam } \\
\text { folat }\end{array} \\
\text { (mcg) }\end{array}$ & $\begin{array}{c}\text { Vitamin } \\
\text { B12 } \\
\text { (mcg) }\end{array}$ \\
\hline 1 & 1,0 & 115,7 & 2,4 & 16,5 & 500 & 500 & 6,0 & 23,14 & 0,48 \\
\hline 2 & 1,2 & 141,9 & 1,5 & 16,5 & 500 & 500 & 7,2 & 28,3 & 0,3 \\
\hline 3 & 0,63 & 66,4 & 1,26 & 16,5 & 500 & 500 & 3,8 & 13,2 & 0,25 \\
\hline 4 & 0,76 & 102,8 & 1,5 & 16,5 & 500 & 500 & 4,6 & 20,5 & 0,3 \\
\hline 5 & 0,8 & 152,5 & 2,1 & 16,5 & 500 & 500 & 4,8 & 30,5 & 0,42 \\
\hline 6 & 0,65 & 94,25 & 0,95 & 16,5 & 500 & 500 & 3,9 & 18,8 & 0,19 \\
\hline 7 & 0,2 & 28,1 & 0,6 & 16,5 & 500 & 500 & 1,21 & 5,62 & 0,12 \\
\hline Total & 5,24 & 701,6 & 10,31 & 16,5 & 500 & 500 & 31,51 & 140,06 & 2,06 \\
\hline Rata-rata & 0,74 & 100,2 & 1,47 & 16,5 & 500 & 500 & 4,50 & 20,0 & 0,29 \\
\hline
\end{tabular}

Berdasarkan tabel 4 menurut tingkat konsumsi vitamin B6, Asam folat, dan vitamin B12 dari hasil rata-rata $\%$ tingkat konsumsi vitamin B6 subjek dalam kategori kurang (4,50\%), tingkat konsumsi asam folat dalam kategori kurang $(20,0 \%)$ dan tingkat konsumsi untuk vitamin B12 dalam katagori kurang (0,29\%).

\section{PEMBAHASAN \\ Karakteristik Subjek \\ Usia}

Berdasarkan penelitian, pasien stroke di BRSUD Tabanan diketahui bahwa usia penderita stroke paling banyak berusia $\geq 55$ tahun sebanyak 5 orang (71\%). Hasil penelitian Lestari (2010) bahwa kejadian stroke pada usia $\geq 55$ tahun lebih besar dibandingkan dengan usia 40-55 tahun. Hasil penelitian yang relevan lainnya menyatakan bahwa peningkatan risiko seseorang terjadinya stroke seiring denganbertambahnya usia. insiden berlipat ganda setiap dekade setelah usia 45 tahun dan lebih dari $70 \%$ dari semua stroke terjadi di atas usia 65 tahun. Dari perkiraan 795.000 stroke baru atau berulang yang terjadi di Amerika Serikat setiap tahun. , sekitar 145, 000 akan menghasilkan kematian (Lloyd-Jones, 2010). Hasil penelitian tersebut sejalan dengan hasil penelitian yang dilakukan oleh Cintya dkk (2012) tentang gambaran faktor risiko dan tipe stroke, yang mana didapatkan kejadian tertinggi stroke iskemik maupun hemoragic terjadi pada usia diatas 50 tahun $(81,25 \%)$ dan sisanya terjadi pada umur dibawah 50 tahun, dengan puncaknya pada usia diatas 65 tahun.

\section{Jenis kelamin}

Hasil penelitian ini menunjukkan bahwa jenis kelamin perempuan mendominasi yaitu sebanyak 4 orang (57\%) mengalami stroke. Berbeda dengan hasil peneilitan Sofyan, dkk (2015) bahwa dari 77 orang subjek 
yang diteliti dijumpai 40 orang berjenis kelamin laki-laki $(51,9 \%)$ dan 37 orang $(48,1 \%)$ berjenis kelamin perempuan. Laki-laki lebih cenderung berisiko mengalami stroke karena kejadian stroke pada perempuan meningkat pada usia pasca menopause, karena sebelum menopause perempuan dilindungi oleh hormone esterogen yang berperan dalam meningkatkan HDL, dimana HDL berperan penting dalam pencegahan proses aterosklerosis.

\section{Pekerjaan}

Hasil penelitian yang dilakukan pada 7 orang subjek penelitian didapatkan hasil mayoritas subjek bekerja sebagai wiraswasta sebanyak 4 orang (57\%). Hasil analisis hubungan antara pekerjaan dengan kejadian stroke menunjukkan bahwa sebagian besar responden bekerja lain-lain, wiraswata dan pegawai negeri. Hasil penelitian Kristiyawati (2008)Faktor risiko yang diketahui sebelum terkena serangan stroke sebanyak 13 orang $(48,1 \%)$ bekerja lain-lain, 10 orang $(66,7 \%)$ wiraswasta dan 10 orang $(71,4 \%)$ pegawai negeri, sedangkan faktor risikonya diketahui saat serangan stroke berjumlah 14 orang $(51,9 \%)$ bekerja lain-lain, 5 orang $(33,3 \%)$ wiraswasta dan 4 orang $(28,6 \%)$ pegawai negeri, sisanya menyebar tidak bekerja, karyawan swasta, buruh pabrik, pedagang, dan petani. Hasil uji statistik diperoleh nilai $\mathrm{p}=0,087$ maka dapat disimpulkan tidak ada hubungan yang signifikan antara pekerjaan dengan kejadian stroke.

\section{Status Gizi}

Hasil penelitian menunjukkan bahwa 1 orang (14\%) mengalami gizi buruk, 1 orang (14\%) overweight, dan 5 orang $(72 \%)$ gizi baik. Status gizi pasien tersebut dipengaruhi oleh pasien kurang nafsu makan dalam jangka waktu yang lama. Hal tersebut sejalan dengan penelitian Ritonga, (2018) yang dijadikan subjek sebanyak 35 orang dan diperoleh hasil bahwa sebagian besar status gizi pada pasien stroke adalah kurus yaitu sebanyak 23 orang $(65,71 \%)$ dan sebagian kecil status gizi pada pasien stroke adalah gemuk yaitu sebanyak 3 orang $(8,85 \%)$. Pasien yang mengalami gangguan gizi disebabkan oleh gejala yang timbul akibat serangan stroke yang dialami seperti mual, muntah, dan gangguan menelan sehingga banyak dijumpai pasien stroke yang menjalani rawat inap menggunakan alat bantu Nasogastric Tube (NGT) untuk memenuhi kebutuhan nutrisinya.

\section{Riwayat Penyakit Subjek Hipertensi}

Hasil penelitian didapatkan data bahwa dari 7 subjek 6 orang (86\%) mengalami hipertensi. Hipertensi akan memacu munculnya timbunan plak pada pembuluh darah besar (aterosklerosis). Timbunan plak akan menyempitkan lumen/diameter pembuluh darah. Plak yang tidak stabil akan mudah pecah dan terlepas. Plak yang terlepas meningkatkan risiko tersumbatnya pembuluh darah otak yang lebih kecil. Bila ini terjadi maka, akan terjadi stroke (Jayanti, 2015). Hal tersebut didukung oleh hasil penelitian Khairatunnisa (2017) Berdasarkan hasil uji statistik didapatkan bahwa terdapat hubungan antara faktor hipertensi terhadap kejadian stroke, dengan nilai OR sebesar 6,18 (95\% CI: 2,46 - 15,51). Hal ini berarti bahwa pasien yang menderita stroke memiliki risiko 6,18 kali dengan hipertensi dibandingkan dengan yang tidak menderita stroke.

\section{Hiperkolestrolemia}

Hasil penelitian menurut karakteristik riwayat penyakit hiperkolestrolemia terdapat $2(29 \%)$ memiliki riwayat hiperkolestrolemia. Hal tersebut di dukung oleh hasil penelitian Linda, (2010) yang dilakukan pada 30 responden didapatkan hasil mayoritas responden memiliki kolesterol tinggi sebanyak 20 orang $(66,7 \%)$. Penderita yang mengalami stroke iskemik dan hemoragik sama-sama memiliki kolesterol yang tinggi. Kolesterol dibutuhkan sebagai salah satu sumber energy, untuk membentuk dinding sel dalam tubuh dan sebagai pertahanan dasar hormone steroid. Akan tetapi jika kolesterol dalam tubuh berlebih akan menyebabkan aterosklerosis yaitu penyempitan atau pengerasan pembuluh darah yang menyebabkan stroke.

\section{Kebiasaan Merokok}

Berdasarkan hasil penelitian menyatakan bahwa 1 orang (14\%) merokok dengan kategori kadang-kadang. Kebiasaan merokok subjek akan mengakibatkan timbulnya penyakit seperti aterosklerosis dan hipertensi yang merupakan faktor risiko utama stroke. Hasil penelitian didukung oleh penelitian sebelumnya bahwa merokok berisiko 2,42 kali terkena troke. Rokok mengandung bahan kimia toksik diantara adalah nikotin, tar, karbon monoksida, ammonia, dan lain-lain. Nikotin adalah kandungan utama dalam rokok. Apabila merokok, nikotin akan masuk kedalam sirkulasi darah kemudian masuk kedalam otak. Nikotin yang masuk kedalam otak akan menyempitkan pembuluh darah pada otak sehingga aliran darah ke otak terhambat sehingga sel-sel otak rusak dan mati yang kemudian dikenal sebagai stroke (Jayanti, 2015). 


\section{Konsumsi Zat Gizi Subjek \\ Konsumsi Vitamin B6}

Berdasarkan rata-rata tingkat konsumsi Vitamin B6 pada pasien stroke. Rerata tingkat konsumsi B6 subjek memiliki asupan zat gizi kurang $(<80 \%)$. Hal ini sejalan dengan hasil penelitian Riska (2011) sebagian besar $(52,2 \%)$ asupan vitamin B6 subjek penelitian dalam kategori defisiensi tingkat berat jika dibandingkan dengan AKG. Kurangnya asupan vitamin B6 maupun rendahnya status vitamin B6 dalam tubuh dapat menyebabkan tingginya kadar homosistein dalam darah. Hasil penelitian tersebut menunjukkan bahwa asupan vitamin B6 pada subjek hiperhomosisteinemia ringan tergolong defisiensi tingkat berat $(52,2 \%)$.

\section{Konsumsi Vitamin B12}

Berdasarkan hasil penelitian, untuk tingkat konsumsi vitamin B12 pada pasien stroke sebanyak 7 orang subjek atau sebesar $100 \%$ memiliki asupan kurang (<80\%). Hal ini sejalan dengan hasil penelitian Riska (2011) menunjukkan bahwa asupan vitamin B12 subjek termasuk dalam kategori defisiensi tingkat berat mengalami hiperhomosisteinemia ringan sebesar 43,4\%. Hasil penelitian tersebut secara analisis statistik menunjukkan hubungan yang bermakna antara asupan vitamin B12 dengan kejadian stroke. Hal ini sesuai dengan teori, vitamin B12 terlibat dalam satu karbon metabolisme neurotransmitter dan fosfollifid dalam sistem saraf.

Hasil penelitian yang dilakukan Prajitmazum, dkk (2017) menunjukkan bahwa Vitamin B12 sangat penting untuk metabolisme folat, erythropoiesis, pengembangan saraf, dan fungsi sistem saraf. Kekurangan vitamin B12 menyebabkan manifestasi sistem saraf pusat dan hematologis. Vitamin B12 dan homosistein memiliki tingkat berbanding terbalik karena kekurangan vitamin B12 mencegah konversi homosistein menjadi metionin yang mengarah pada peningkatan kadar serum homosistein. Pasien dengan peningkatan kadar homosistein karenanya berisiko serebrovaskular, komplikasi kardiovaskular.

\section{Konsumsi Asam Folat}

Berdasarkan hasil penelitian terhadap tingkat konsumsi asam folat pasien stroke, sebanyak 7 orang subjek atau sebesar $100 \%$ memiliki asupan kurang $(<80 \%)$. Hal ini sejalan dengan hasil penelitian Riska (2011) asupan asam folat seluruh subjek dalam penelitiannya dalam kategori defisiensi dibandingkan dengan AKG. Hasil penelitiannya menunjukkan asupan asam folat sebesar 60,8\% subjek dengan hiperhomosisteinemia ringan tergolong defisiensi tingkat berat. Hasil penelitian ini sesuai dengan teori yang menyebutkan bahwa asam folat bersama vitamin B6 dan B12 berperan dalam menekan kadar homosistein total dalam darah. Menurut Mardiana, (2017) Vitamin B6, B12, dan asam folat merupakan zat gizi yang mempunyai peran penting dalam menjaga kesehatan saraf. Vitamin B6, B12 dan asam folat melindungi pembuluh darah arteri dari kerusakan akibat pengaruh homosistein. Oleh karena itu, jika terjadi defisiensi vitamin B6, B12 dan asam folat tersebut akan mengakibatkan kadar homosistein dalam darah meningkat dan apabila kadar homosistein meningkat akan menyebabkan terjadinya aterosklerosis yaitu penyempitan atau pengerasan pembuluh darah yang menyebabkan stroke.

\section{KESIMPULAN}

Total subjek penelitian berjumlah 7 orang, sebanyak 5 orang $(71 \%)$ berusia $\geq 55$ tahun, Jenis kelamin subjek terbanyak mengalami stroke adalah perempuan dengan jumlah 4 orang (57\%), Distribusi jenis pekerjaan wiraswasta sebanyak 4 orang (57\%), PNS 1 orang (14\%) dan tidak bekerja sebanyak 2 orang (29\%), menurut status gizi 1 orang (14\%) gizi buruk, 1 orang (14\%) overweight, dan 5 orang (72\%) gizi baik. Subjek yang memiliki riwayat penyakit hipertensi 6 orang $(86 \%)$, dan yang memiliki riwayat penyakit hiperkolestrolemia 2 orang (29\%), sebanyak 1 orang (14\%) memiliki kebiasaan merokok.

Tingkat konsumsi Vitamin B6, B12, dan asam folat pada pasien stroke, diketahui seluruh subjek memiliki tingkat konsumsi kurang (<80\%) dengan rincian vitamin B6 (4,50\%), B12 (0,29\%), Asam folat ( 20,0\%)..

\section{SARAN}

Pada penelitian ini dilakukan pengumpulan data asupan dengan metode food weighing, namun tidak menimbang makanan pokok (bubur) dikarenakan pada saat penelitian tidak diperbolehkan untuk melakukan penimbangan, serta tidak mengumpulkan data asupan supplemen. Oleh karena itu, diharapkan agar pada penelitian berikutnya dapat menimbang seluruh makanan dan menghitung asupan vitamin B yang dikonsumsi dalam bentuk suplemen. 
Berdasarkan penelitian yang telah dilakukan, diketahui bahwa kandungan vitamin B6, B12, dan asam folat pada standar menu untuk pasien stroke masih kurang dengan rincian rata-rata vitamin B6 1,57 mg $(9,5 \%)$, vitamin B12 4,15 $\mu \mathrm{g}$ (0,83\%), dan asam folat 211,12 $\mu \mathrm{g}$ (42,2\%). Maka disarankan untuk dapat berkoordinasi dengan tim asuhan gizi untuk dapat memberikan bahan makanan yang tinggi akan vitamin B6, B12, dan asam folat atau untuk pemberian supplemen agar dapat memenuhi kebutuhan zat gizi yang diperlukan.

Perlu dilakukan penelitian selanjutnya agar ahli gizi dapat memformulasikan makanan yang tinggi vitamin B6, B12, dan asam folat dalam menu pasien stroke.

\section{DAFTAR PUSTAKA}

American Health Asosiation [AHA] 2017. http://www.strokeassociation.org./STROKE ORG/General/WordStroke-day.

Birawa, A.B.P., Amalia, L. 2015. Stroke pada usia muda. CDK-233/vol. 42 no.10,th.2015.

Clarke, R dan Armitage, J. 2000. Vitamin supplement and cardiovascular risk: review of the randomized trials of homocysteine-lowering vitamin supplement.

Direktorat pencegahan dan pengendalian penyakit, Kementrian Kesehatan RI.

Dewi, R.T.A. 2017. Pengaruh latihan bola lunak bergerigi dengan kekuatan genggam tangan pada pasien stroke non hemoragik di RSUD Prof.DR. Margono Soekarjo Purwokerto. Bachelor thesis, Universitas Muhammadiyah Purwokerto.

Ghani,L., Mihardja, L.K., Delima.2015. Faktor resiko dominan penyakit stroke di Indonesia. Bulletin penelitian kesehatan, vol.44, no 1.

Jatiningrum, K.S. 2018. Profil faktor risiko stroke pasien usia tua dan usia muda di RSUD Jombang Tahun 2016-2017. Universitas Muhammadiyah Malang.

Jayanti, A.A. 2015. Hubungan hipertensi dengan kejadian stroke di Sulawesi Selatan.

Kemenkes RI. 2013. Riset kesehatan dasar; RISKESDAS. Jakarta: Balitbang Kemenkes RI.

Khaeratunnisa dan Sari, D.M. 2017. Faktor resiko yang berhubungan dengan kejadian stroke pada pasien di RSU H. Sahudin Kutacane Kabupaten Aceh Tenggara. Jurnal jumantik volume 2 nomor 1.

Kristiyawati, S.P. 2008. Analisis faktor risiko yang berhubungan dengan kejadian stroke di rumah sakit panti wilasa citarum semarang.

Mardiana, 2017. Hubungan kadar vitamin B12 dengan homosistein plasma pada penderita preeklampsia dan kehamilan normal [tesis]. Padang: Uiversitas Andalas Padang.

Pajri, R.N., Safri.,Dewi, Y.I. 2018. Gambaran faktor-faktor penyebab terjadinya stroke.

Patricia, H., Kembuan, M.A.H.N., Tumboimbela, M.J. 2015. Karakteristik penderita stroke iskemik yang di rawat inap di RSUP Prof. DR.R.D.Kandaou Manad Tahun 2012-2013. Jurnal e-clinic (eCL), volume 3, no 1.

Perawaty., Dahlan, P., Astuti, H. 2014 .Pola makan dan hubungannya dengan kejadian stroke di RSUD dr. Doris Sylvanus palangka Raya. Jurnal gizi dan dietetik Indonesia vol.2 no 2.

Ritonga, E.P. 2018. Gambaran status gizi pada pasien stroke pasca rawat inap di RA IV Neurologi RSUP.H.Adam Malik Medan.

Rusnoto dan Setyono,D.F.2018. Hubungan kolestrolemia obesitas dan riwayat penyakit hipertensi keluarga dengan kejaidan hipertensi di Desa Megawon Kudus, Universitas Muhamadiyah Purwokerto. 
Suryanto. 2018. Gambaran Diabetes Millitus dan hipertinsi pada penderita stroke jurnal keperawatan volume 10 no. 2 , hal 125 - 129 .

Susilawati, F dan Nurhayati. 2018. Faktor resiko kejadian stroke di rumah sakit. Jurnal keperawatan, volume XIV, no. 1.

Sofyan, A.M., Sihombing, I.Y., Hamra, Y. 2015. Hubungan umur, jenis kelamin, dan hipertensi dengan kejadian stroke.

Triantari R.2011. Hubungan asupan vitamin B6, vitamin B12, asam folat, aktifitas fisik dan kadar homosisten dengan status kognitip lansia. Semarang: Universitas Diponegoro

Widyayanto, I. 2014. Hubungan antara kadar homosistein serum fase akut dengan kemandirian fungsional jangka pendek pasien stroke iskemik.

Yunita, H dan Almasyuri. 2012. Kandungan vitamin B6, B9, B12 dan beberapa jenis daging, telur, ikan dan udang laut di Bogor dan sekitarnya. 